\title{
Copy number variation of the SELENBP1 gene in schizophrenia
}

\author{
Shirly Amar ${ }^{1}$, Ofer Ovadia ${ }^{2}$, Wolfgang Maier ${ }^{3}$, Richard Ebstein ${ }^{4}$, RH Belmaker ${ }^{1}$, Dan Mishmar², Galila Agam ${ }^{*}$
}

\begin{abstract}
Background: Schizophrenia is associated with rare copy-number (CN) mutations. Screening for such alleles genome-wide, though comprehensive, cannot study in-depth the causality of particular loci, therefore cannot provide the functional interpretation for the disease etiology. We hypothesized that CN mutations in the SELENBP1 locus could associate with the disorder and that these mutations could alter the gene product's activity in patients.

Methods: We analyzed SELENBP1 CN variation (CNV) in blood DNA from 49 schizophrenia patients and 49 controls (cohort A). Since CN of genes may vary among tissues, we investigated SELENBP1 CN in age- sex- and postmortem interval-matched cerebellar DNA samples from 14 patients and 14 controls (cohort B). Since CNV may either be denovo or inherited we analyzed CNV of the SELENBP1 locus in blood DNA from 26 trios of schizophrenia probands and their healthy parents (cohort C). SELENBP1 mRNA levels were measured by real-time PCR.

Results: In cohort A reduced CN of the SELENBP1 locus was found in four patients but in none of the controls. In cohort B we found reduced CN of the SELENBP1 locus in two patients but in none of the controls. In cohort C three patients exhibited drastic CN reduction, not present in their parents, indicating de-novo mutation. A reduction in SELENBP1 mRNA levels in the postmortem cerebellar samples of schizophrenia patients was found.

Conclusions: We report a focused study of CN mutations in the selenium binding-protein1 (SELENBP1) locus previously linked with schizophrenia. We provide evidence for recurrence of decreased CN of the SELENBP1 locus in three unrelated patients' cohorts but not in controls, raising the possibility of functional involvement of these mutations in the etiology of the disease.
\end{abstract}

\section{Background}

Genomic deletion, duplication and insertion, designated copy number variation (CNV), are found in all human beings, could be either common, rare or de novo [1] and may influence gene expression and phenotypic variation [2-6]. CNV have been linked to the pathogenesis of both monogenic and complex disorders [7-13] including brain-related disorders such as schizophrenia [14-17]. Specifically, twenty five percent of subjects carrying a $3-\mathrm{Mb}$ microdeletion in chromosome 22q11.2 exhibited psychiatric manifestations including autism, attention-deficit hyperactivity disorder (ADHD) and schizophrenia [18]. Recent whole genome CNV screens revealed significant association of rare CNVs in several

\footnotetext{
* Correspondence: dmishmar@bgu.ac.il; galila@bgu.ac.il

'Psychiatry Research Unit, Faculty of Health Sciences, Ben-Gurion University of the Negev, and Mental Health Center, Beersheva, Israel

${ }^{2}$ Department of Life Sciences and National Institute of Biotechnology (NIBN), Ben-Gurion University of the Negev, Beer Sheva, Israel
}

loci with schizophrenia [16,19-21]. Confirmed de novo CNV mutations were significantly associated with schizophrenia and were about eight times more frequent in sporadic (but not in familial) cases of schizophrenia as compared to unaffected controls [21]. These findings suggest that CNVs in certain loci are more prevalent in schizophrenia patients as compared to controls.

Chromosome 1q21.3 harbors known CNVs in the general population $[3,5,22,23]$. Interestingly, the 1q21-22 region has been reported to be linked with schizophrenia with a likelihood of linkage (LOD) score of 6.5 (Brzustowicz and others, 2000). The gene encoding selenium binding protein (SELENBP) 1 which has been mapped to this region has recently been reported to be associated with schizophrenia [24]. Moreover, SELENBP1 mRNA levels were up-regulated in postmortem brain and in blood cells from schizophrenia patients $[25,26]$. Indeed, selenium is implicated in neuroprotection [27-32] and selenium deficiency has been reported

C Biomed Central

C 2010 Amar et al; licensee BioMed Central Ltd. This is an Open Access article distributed under the terms of the Creative Commons Attribution License (http://creativecommons.org/licenses/by/2.0), which permits unrestricted use, distribution, and reproduction in any medium, provided the original work is properly cited. 
to be associated with increased schizophrenia rates [33]. We therefore hypothesized that CNV including the SELENBP1 locus is associated with schizophrenia. To this end we compared blood DNA from schizophrenia patients with healthy controls originating from the same ethnicity group. Since CNV varies among tissues $[34,35]$ we then studied SELENBP1 CNV in postmortem cerebellum of schizophrenia patients and unrelated matched controls. Among other brain regions the cerebellum has also been implicated as involved in the pathophysiology of schizophrenia [36,37]. Since CNV may either be de novo or inherited [1] we further analyzed $\mathrm{CNV}$ of the SELENBP1 gene in trios of schizophrenia probands and their healthy parents in whole blood DNA. In order to find out whether CNV in the SELENBP1 locus associates with the previously reported up-regulation of brain SELENBP1 in schizophrenia, we measured SELENBP1 mRNA levels in the same postmortem cerebellar specimens studied for $\mathrm{CNV}$.

\section{Materials and methods \\ Patient cohorts}

Discovery cohort: Blood DNA samples from 49 unrelated schizophrenia patients and 49 healthy controls originated from the Bedouins of the Negev population. The samples from the patient group and from the normal controls were collected for separate previously described studies after informed consent [38-40]. The original protocols were approved by the Helsinki committee (Beer-Sheva). Another cohort was age- sex- and postmortem interval-matched cerebellar samples from 14 schizophrenia patients and 14 matched normal controls were obtained from the Victoria Brain Tissue Repository at the Mental Health Research Institute of Victoria, Melbourne, Australia. Their detailed demographic data are summarized in Table 1. Permission to carry out studies was obtained from the Ethics Committee of the Victoria Institute of Forensic Medicine and the North Western Mental Health Program Behavioural and Psychiatric Research and Ethics Committee. An unrelated replication cohort of 78 blood DNA samples from 26 unrelated schizophrenia patients and their healthy parents originated from Israeli Arabs recruited for previously described studies after informed consent $[41,42]$. The original protocol was approved by the Helsinki committee (Beer-Sheva). All samples of the three cohorts became de-identified prior to our study.

\section{DNA purification}

DNA for the dertermination of CNV was extracted from whole blood using standard techniques (Phenol-chloroform). DNA concentration and quality was quantified using a Nanodrop ND-1000 spectrophotometer
(Nanodrop Technologies, Wilmington, DE). DNA concentration was brought to $50 \mathrm{ng} / \mu \mathrm{l}$ for the SELENBP1 amplification and to $5 \mathrm{ng} / \mu \mathrm{l}$ for the Factor 8 (F8, a gene locus lacking $\mathrm{CNV}$ ) amplification.

\section{RNA purification and CDNA synthesis}

For the determination of SELENBP1 mRNA levels RNA purification, determination of purity and concentration and cDNA synthesis were carried out as previously described [43].

\section{Measurement of DNA copy number by real time PCR}

Quantitative PCR was performed using the F8 gene locus as a reference for normalization of the real time PCR experiments. This gene was chosen since it does not exhibit CNV [44]. F8 forward (CTACCATCCAGGCTGAGGTTTATG) and reverse (CACCAACAGCATGAAGACT GACA) primers were used as previously described [44]. A fragment of 254 bp of exon 12 of the SELENBP1 gene was amplified using the forward (CCACCAGGGAAGGCTCTGTGA) and reverse (GGGTGCCAAGAGAGAGCAGAA) primers designed using the program OLIGO and based on the published DNA sequence in Genbank (NM_003944).

Real-time quantitative PCR was performed using Rotor Gene 3000 (Corbett Research, Sydney, Australia). Reactions were carried out in a final volume of $25 \mu \mathrm{l}$ consisting of either $50 \mathrm{ng} / \mu \mathrm{l}$ for the SELENBP1 amplification or $5 \mathrm{ng} / \mu \mathrm{l}$ for Factor 8 amplification, $250 \mathrm{nM}$ forward and reverse primers each and $12.5 \mu \mathrm{l}$ ABsolute QPCR SYBR Green Mix (ABgene, Surrey, UK) including dNTPs, Taq DNA polymerase and reaction buffer. Real-time PCR assays of SELENBP1 and F8 CNV included an initial step of $15 \mathrm{~min}$ at $95^{\circ} \mathrm{C}$ to activate Taq polymerase, followed by 40 cycles comprising denaturing at $95^{\circ} \mathrm{C}$ for $15 \mathrm{sec}$, annealing at $58.8^{\circ} \mathrm{C}$ for 20 seconds and extension at $72^{\circ} \mathrm{C}$ for $15 \mathrm{sec}$. The reaction was concluded with 10 minutes $72^{\circ} \mathrm{C}$ as a final extension step. The fluorescence of the accumulating product was acquired for each cycle after an additional 5 seconds melting step at $78^{\circ} \mathrm{C}$. Fluorescence monitoring occurred at regular intervals during the annealing phase and continuously throughout the melting phase. The cycle at which fluorescence exceeded background, the corrected threshold cycle $\left(C_{\mathrm{t}}\right)$, is negatively related to the initial copy number in a given DNA sample. In order to assess the relative copy numbers of SELENBP1 each of the runs included a calibration curve of both F8 and SELENBP1 using a DNA pool which included four samples having the highest $\mathrm{Ct}$ values. The F8 calibration curve was generated using DNA concentrations of $1 \times 10^{9}, 10^{7}, 10^{5}, 10^{4}$ and $10^{3}$ copies/ $\mu$ l. Quantification of each sample was obtained by interpolation of $C_{t}$ values from the generated 
Table 1 Postmortem brain cohort's demographic data

\begin{tabular}{|c|c|c|c|c|c|c|c|c|c|c|c|}
\hline \multicolumn{4}{|c|}{$\begin{array}{l}\text { Schizophrenia } \\
\text { patients }\end{array}$} & \multirow[b]{2}{*}{ Dol } & \multirow[b]{2}{*}{ CoD } & \multirow[b]{2}{*}{ Neuroleptics } & \multicolumn{4}{|c|}{ Control subjects } & \multirow[b]{2}{*}{ CoD } \\
\hline Age & Sex & PMI & $\mathrm{pH}$ & & & & Age & Sex & PMI & $\mathrm{pH}$ & \\
\hline 38 & $\mathrm{~m}$ & 36.00 & 6.07 & 11 & Hanging & FD (25 mg, 3 weekly) & 35 & $m$ & 35.00 & 6.13 & $\begin{array}{l}\text { Coronary artery } \\
\text { atheroma }\end{array}$ \\
\hline 35 & $\mathrm{~m}$ & 47.00 & 6.27 & 17 & Perforated gastric ulcer & FD (50 mg, 3 weekly) & 38 & $\mathrm{~m}$ & 44.00 & 6.19 & $\begin{array}{l}\text { Coronary artery } \\
\text { atheroma }\end{array}$ \\
\hline 47 & $\mathrm{~m}$ & 41.50 & 6.52 & 21 & Multiple injuries & Chlorpromazine (400 mg daily), & 48 & $\mathrm{~m}$ & 24.00 & 6.37 & $\begin{array}{l}\text { Coronary artery } \\
\text { atheroma }\end{array}$ \\
\hline \multirow[t]{3}{*}{53} & $\mathrm{~m}$ & 43.00 & 6.23 & 7 & Aspiration/food & Haloperidol (150 mg, 2 weekly) & 53 & $\mathrm{~m}$ & 12.00 & 6.34 & $\begin{array}{l}\text { Pulmonary } \\
\text { thromboembolism }\end{array}$ \\
\hline & & & & & & ${ }^{*}$ Chlorpromazine (200 mg daily) & & & & & \\
\hline & & & & & & $\begin{array}{l}\text { LAST RECORDED } 14 / 6 / 88,6 \text { yrs prior to } \\
\text { death }\end{array}$ & & & & & \\
\hline 69 & m & 44.50 & 6.38 & 47 & Ischaemic heart disease & Trifluoperazine $\mathrm{HCl}$ (5 mg, daily) & 62 & $\mathrm{~m}$ & 66.00 & 6.50 & Acute myocardial infarct \\
\hline \multirow[t]{2}{*}{61} & m & 37.50 & 6.46 & 38 & Ischaemic heart disease & *FD (62.5 mg, 2 weekly) & 68 & $\mathrm{~m}$ & 69.00 & 6.59 & $\begin{array}{l}\text { Coronary artery } \\
\text { atheroma }\end{array}$ \\
\hline & & & & & & $\begin{array}{l}\text { LAST RECORDED 22/1/92, } 4 \text { yrs prior to } \\
\text { death }\end{array}$ & & & & & \\
\hline \multirow[t]{2}{*}{65} & $\mathrm{~F}$ & 50.00 & 6.35 & 18 & $\begin{array}{l}\text { Ruptured abdominal } \\
\text { aneurysm }\end{array}$ & FD (25 mg, 2 weekly), & 66 & $\mathrm{~F}$ & 43.00 & 6.37 & Acute myocardial infarct \\
\hline & & & & & & Haloperidol (5 mg, daily) & & & & & \\
\hline \multirow[t]{2}{*}{57} & $\mathrm{~m}$ & 24.00 & 6.06 & 28 & Coronary artery atheroma & ${ }^{*} \mathrm{FD}$ (18.75 mg, 3 weekly), & 57 & $\mathrm{~m}$ & 27.00 & 6.43 & Ischaemic heart disease \\
\hline & & & & & & $\begin{array}{l}\text { LAST RECORDED 29/1/93, } 3 \text { yrs prior to } \\
\text { death }\end{array}$ & & & & & \\
\hline \multirow[t]{2}{*}{69} & m & 48.00 & 6.44 & 6 & $\begin{array}{l}\text { Carbon monoxide } \\
\text { poisoning }\end{array}$ & *Haloperidol (7 mg, daily) & 68 & $\mathrm{~m}$ & 41.00 & 6.06 & Aortic stenosis \\
\hline & & & & & & $\begin{array}{l}\text { LAST RECORDED } 26 / 11 / 91,5 \text { yrs prior } \\
\text { to death }\end{array}$ & & & & & \\
\hline \multirow[t]{2}{*}{23} & $\mathrm{~m}$ & 78.00 & 6.19 & 5 & Multiple injuries & *Haldol (150 mg, 4 weekly), & 22 & $\mathrm{~m}$ & 51.00 & 6.58 & Exsanguination \\
\hline & & & & & & $\begin{array}{l}\text { LAST ADMINISTERED } 3 \text { weeks prior to } \\
\text { death }\end{array}$ & & & & & \\
\hline \multirow[t]{2}{*}{26} & $\mathrm{~m}$ & 52.00 & 6.39 & 2 & $\begin{array}{l}\text { Carbon monoxide } \\
\text { poisoning }\end{array}$ & *Haldol (75 mg, 2 weekly), & 25 & $\mathrm{~m}$ & 35.00 & 6.15 & $\begin{array}{l}\text { Right ventricular } \\
\text { hypertrophy }\end{array}$ \\
\hline & & & & & & $\begin{array}{l}\text { LAST ADMINISTERED } 2 \text { days prior to } \\
\text { death }\end{array}$ & & & & & \\
\hline 38 & $\mathrm{~F}$ & 20.00 & 6.43 & 17 & Burning & FD (31.25 mg, 2 weekly) & 36 & $\mathrm{~F}$ & 60.00 & 6.40 & Dilated cardiomyopathy \\
\hline \multirow[t]{2}{*}{41} & $\mathrm{~m}$ & 35.00 & 6.64 & 15 & Hanging & ${ }^{*} \mathrm{FD}(25 \mathrm{mg}$, ? weekly) & & & & & \\
\hline & & & & & & $\begin{array}{l}\text { LAST RECORDED 15/11/88, } 9 \text { yrs prior } \\
\text { to death }\end{array}$ & & & & & \\
\hline \multirow[t]{2}{*}{47} & $\mathrm{~F}$ & 50.00 & 6.31 & 20 & Pneumonia & *Respiridone (12 mg, daily), & 47 & $\mathrm{~F}$ & 24.00 & 5.89 & Pulmonary embolus \\
\hline & & & & & & $\begin{array}{l}\text { LAST PRESCRIBED } 6 \text { months prior to } \\
\text { death }\end{array}$ & 32 & $\mathrm{~F}$ & 56.00 & 6.16 & $\begin{array}{l}\text { Coronary artery } \\
\text { atheroma }\end{array}$ \\
\hline
\end{tabular}

$\mathrm{PMI}=$ postmortem interval (hrs); Dol = duration of illness (yrs); CoD = cause of death;

standard curve using the Rotor-Gene software. Corrected $\mathrm{Ct}$ values were calculated as previously described [45] All assays included a no template negative control. All samples were run thrice. The presented results are the average of the three runs. Since $\mathrm{F} 8$ is located on chromosome $\mathrm{X}, K C_{t i}$ values [45] of the women were corrected accordingly.

\section{Measurement of mRNA levels by RT-real time PCR}

Quantitative RT-PCR was performed using the housekeeping gene $\beta$-actin as an internal standard. $\beta$-actin forward (TCCCTGGAGAAGAGCTACG) and reverse (GTAGTTTCGTGGAT GCCACA) primers and SELENBP1 forward (TCATCAGGGAAGGCTCTGTGA) and reverse (GGGTGCCAAGAGAGAGCAGAA) primers were designed using the computer program OLIGO based on the cDNA structure of the genes published in Genebank.

SELENBP1 and $\beta$-actin first strand cDNA synthesis was carried out in separate reactions. One $\mu \mathrm{g}$ RNA was reverse transcribed into cDNA with ReverseiT 1st Strand Synthesis Kit (ABgene, Surrey, UK) for $45 \mathrm{~min}$ at 
$42^{\circ} \mathrm{C}$ in a final $20 \mu \mathrm{l}$ reaction volume containing $1 \mu \mathrm{g}$ total cellular RNA. To obtain PCR results within the linear range of detection, the cDNA products were diluted 1:5 for both SELENBP1 and $\beta$-actin. Real-time quantitative PCR was performed using Rotor Gene 3000 (Corbett Research, Sydney, Australia). Reactions were carried out in a final volume of $25 \mu \mathrm{l}$ consisting of $2 \mu \mathrm{l}$ purified cDNA (SELENBP1 or $\beta$-actin), $250 \mathrm{nM}$ each forward and reverse primers and $12.5 \beta 1$ ABsolute QPCR SYBR Green Mix (ABgene, Surrey, UK) providing dNTPs, Taq DNA polymerase and reaction buffer. SELENBP1 and $\beta$ actin real-time PCR assays included an initial $15 \mathrm{~min}$ at $95^{\circ} \mathrm{C}$ step to activate Taq polymerase, followed by 40 cycles each comprising denaturation at $95^{\circ} \mathrm{C}$ for $15 \mathrm{sec}$, annealing at $58^{\circ} \mathrm{C}$ for 20 seconds, and extension at $72^{\circ} \mathrm{C}$ for $15 \mathrm{sec}$. The fluorescence of the accumulating product was acquired at each cycle after an additional 5 seconds melting step at $78^{\circ} \mathrm{C}$. Each sample was run three times. Final quantification of the mRNA levels was carried out as previously described [46].

\section{Statistical analysis}

In the CNV determination procedure normalized $C_{\mathrm{t}}$ values were not normally distributed. We thus compared the distribution of SELENBP1 normalized $C_{\mathrm{t}}$ values of schizophrenia patients in each of the three cohorts with their respective controls using Kolmogorov-Smirnov two-sample tests [47]. This nonparametric test is sensitive to differences in parameters such as location, dispersion and skewness between distributions [47]. Tests were performed using Systat 9.0 (Systat Software, Inc., CA, USA). As mentioned above, the third cohort was comprised of 26 triads of schizophrenia probands and their healthy parents. Each replicate of each family is designated "sample". A total of 78 samples (26 families $\times 3$ replicates $=78$ samples) were analysed using the program PRIMER v6 (PRIMER-E Ltd, Plymouth, UK). Each sample is represented as a point in a three dimentional space defined by the SELENBP1 normalized $C_{\mathrm{t}}$ values of each of the three family members. We generated a dissimilarity matrix comprising of the Euclidean distances between all possible pairwise sample comparisons after applying a by total sample standardization [48]. Each of these dissimilarity coefficients represents the natural distance between two samples in the distribution of SELENBP1 normalized $C_{\mathrm{t}}$ values among family members [48]. To explore the "natural groupings" of the 78 samples, we used a non-metric multi-dimensional scaling (MDS) [49]. Our aim was to represent the 78 samples as points in low-dimensional space (i.e., 2-d) such that the relative distances apart of all points are in the same rank order as the relative dissimilarities (or distances) of the samples as measured by the dissimilarly matrix described above. A two-dimensional space representation is considered excellent when the stress value is smaller than 0.05 [50]. To test for significant differences between families exhibiting de novo $\mathrm{CNV}$ of the SELENBP1 locus and those in which CNV was inherited we used an analysis of similarity test (ANOSIM) [48], analogous of the standard one-way analysis of variance (ANOVA), but which operates on the dissimilarity matrix described above.

Student's t-test was used to compare SELENBP1 mRNA levels (relative to $\beta$-actin) between patients and controls of the postmortem cerebellar cohort.

\section{Results}

We assessed the variation in copy number of the SELENBP1 locus by real time PCR. Since there is no 'wild type' copy number of SELENBP1 to be used as a reference we normalized the $\mathrm{Ct}$ obtained from each sample by $C_{\mathrm{t}}$ of Factor 8 of the coagulation system, a locus lacking $\mathrm{CNV}$ and hence expected to serve as a normalizing reference for SELENBP1 copy number. We performed 3 case-control comparisons of SELENBP1 CNV pattern. Cohort A: Blood DNA from 49 schizophrenia patients and 49 healthy controls from Israeli Bedouin origin. Since copy number of genes may vary among tissues, we further investigated (Cohort B) SELENBP1 copy number in age- sex- and postmortem interval-matched cerebellar DNA samples from 14 schizophrenia patients and 14 unrelated matched controls originating from the Australian population [51]. Since a CNV may either be de novo or be inherited we analyzed CNV of the SELENBP1 locus in blood DNA from 26 Israeli Arab trios of schizophrenia probands and their healthy parents (Cohort C) Schizophrenia-related differences in CNV of a specific locus have previously been reported either in a qualitative manner [52] or in a statistical supported approach [53]. Here we report our analysis in both ways.

The distribution of the SELENBP1 normalized $C_{\mathrm{t}}$ values characterizing the schizophrenia patients was right skewed in all three cohorts, indicating that the number of cycles required to reach the same threshold level was higher (lower copy number) among some of the schizophrenia patients in each of these three unrelated sample sets. In cohort A one schizophrenia patient exhibited drastic reduction and three patients had moderately reduced gene copy number of the SELENBP1 locus which were not found in any of the control subjects (Figure 1). This qualitative phenomenon did not reflect an overall significant difference in the distribution of normalized $C_{t}$ values of the SELENBP1 locus between the schizophrenia patients and the healthy controls. In the postmortem brain specimens (cohort B) a markedly reduced copy number of SELENBP1 in two schizophrenia specimens was observed (Figure 2). The 


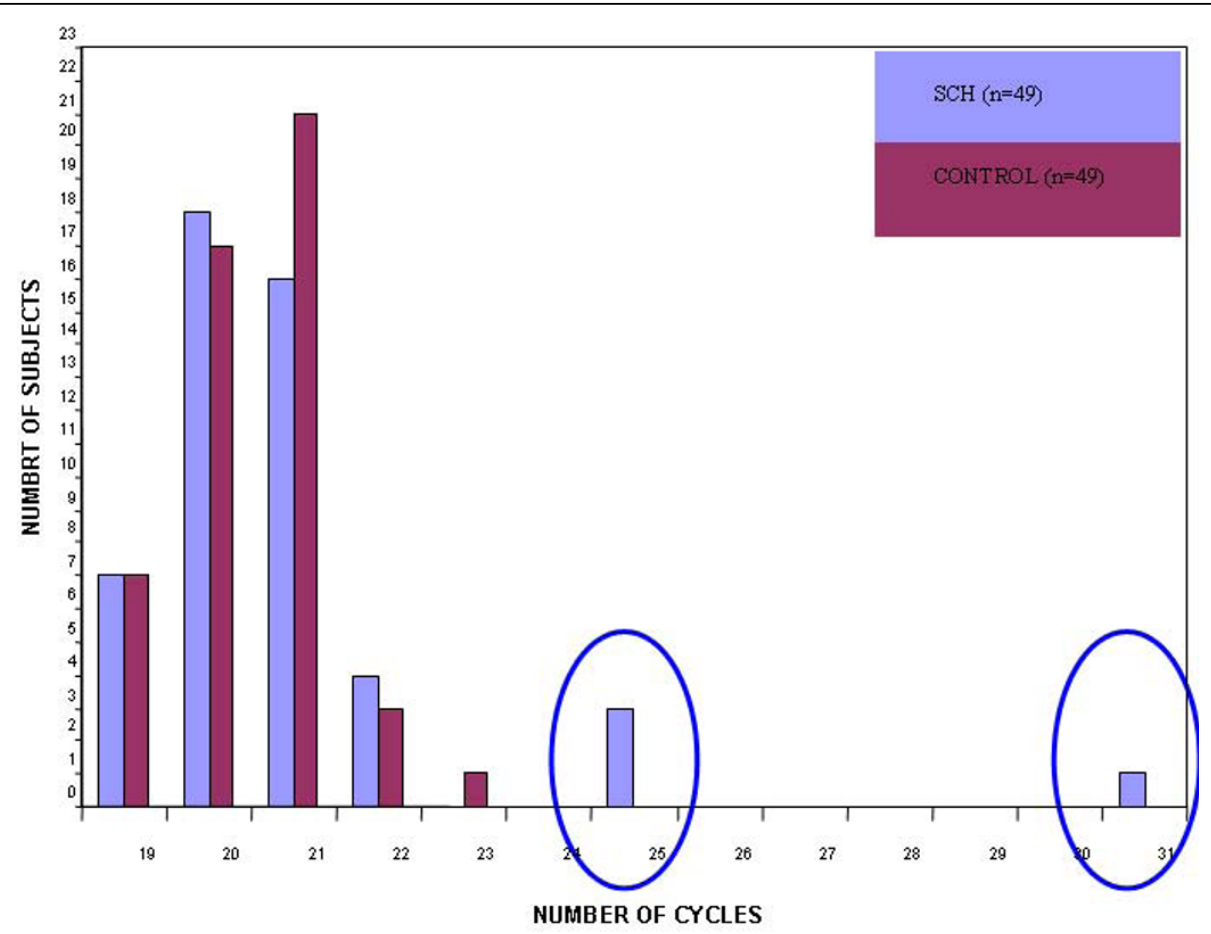

Figure $1 \mathrm{~A}$ histogram of normalized cycle number required to reach a particular fluorescence threshold of the SELENBP1 gene in blood DNA of schizophrenia patients and healthy controls. The distribution of the normalized $C_{t}$ values of SELENBP1 in the patient group is not significantly different from that of the control group (Kolmogorov-Smirnov two-sample test, $p=0.99$ ). Circle denotes reduced copy number.

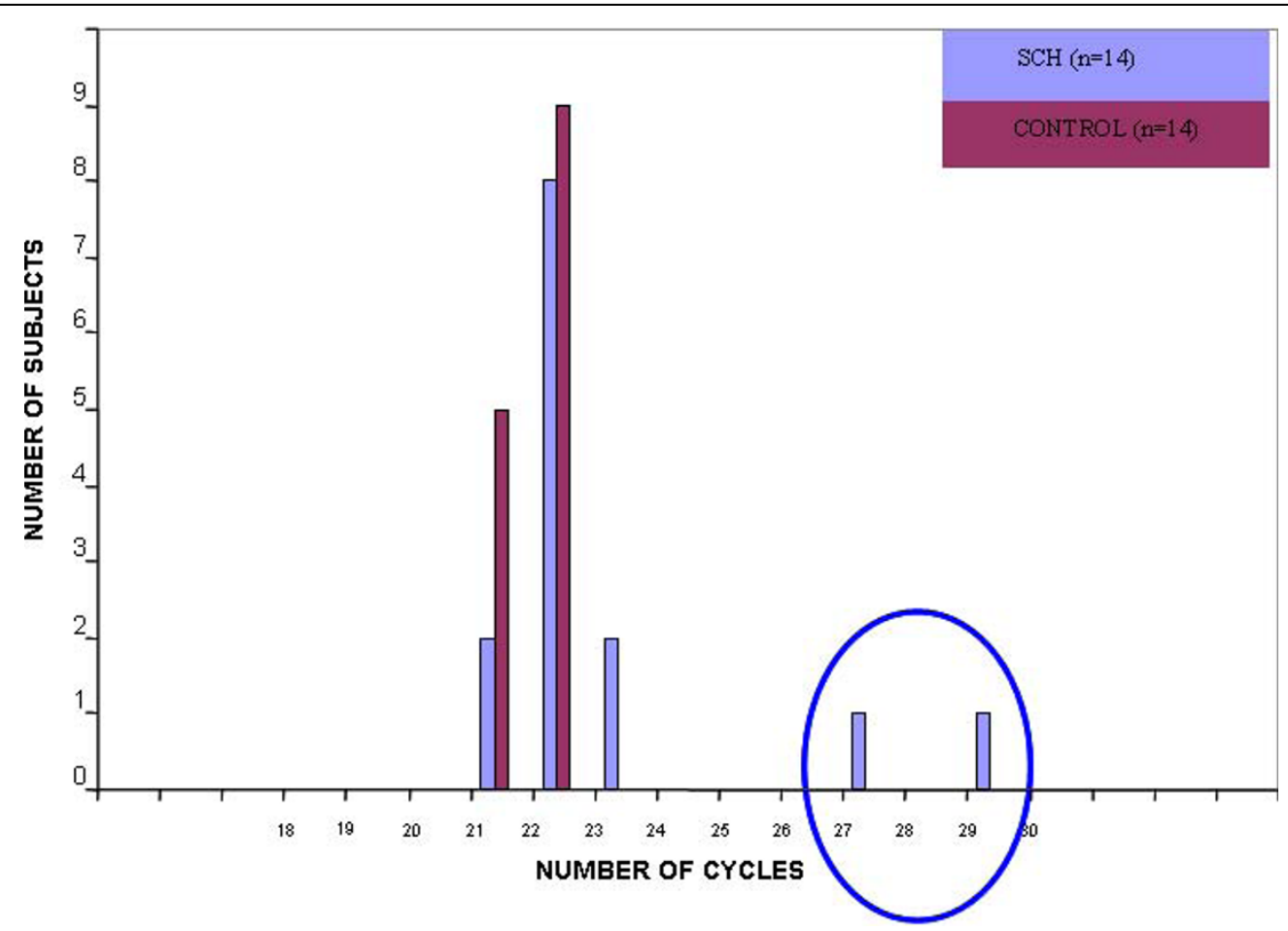

Figure 2 A histogram of normalized cycle number required to reach a particular fluorescence threshold of the SELENBP1 gene in postmortem cerebellum DNA of schizophrenia patients. The distribution of the normalized $C_{t}$ values of SELENBP1 in the patient group differed significantly from that of the control group (Kolmogorov-Smirnov two-sample test, $p=0.038$ ). Circle denotes reduced copy number. 
distribution of the normalized $C_{t}$ values of SELENBP1 differed significantly between the patient and control groups (Kolmogorov-Smirnov two-sample test, $\mathrm{p}=$ 0.038). To discern between inherited and de novo $\mathrm{CNV}$ we analyzed the triads cohort $(\mathrm{C})$ (Figure 3). The distribution of the normalized $C_{\mathrm{t}}$ values of SELENBP1 in the patient group differed significantly from that characterizing the mothers (Kolmogorov-Smirnov two sample test, $\mathrm{p}=0.012$ ), but not the fathers (Kolmogorov-Smirnov two-sample test, $\mathrm{p}=0.87$ ). Three patients showed a drastically reduced copy number of SELENBP1, a phenomenon not observed in any of the healthy parents. Using an arbitrary difference of at least three normalized $C_{\mathrm{t}}$ values between the patient and both of his/her parents as de novo CNV, overall, six families of the 26 exhibited de novo CNV of the SELENBP1 locus. These six families significantly differed from the other families (ANOSIM test, Global $\mathrm{r}=0.658, \mathrm{p}=0.001$ ) (Figure 4). Three of these families were those in whom the probands had the drastically reduced copy number of the SELENBP1 locus. Taken together, rare reduction in CNV of the SELENBP1 locus was found in patients but not in controls of the three studied cohorts.

SELENBP1 mRNA levels in the postmortem cerebellar specimens studied for CNV were about $16 \%$ significantly reduced between patients and controls [controls: $0.170+$ 0.02 Arbitrary Units (AU); patients $0.143+0.02$ AU;
Student's t-test, $\mathrm{n}=14$ in each diagnostic group, $\mathrm{t}=$ -2.18, p $=0.037$ ] with no correlation between SELENBP1 Ct (reflecting copy number) and mRNA levels in the patient group $(r=-0.02)$.

\section{Discussion}

Recent evidence supported the involvement of CNV in the etiology of complex disorders, in general, and in schizophrenia, in particular [10,16,19-21,53-55]. However, most of these reports deal with whole genome screens for CNV [16,19-21,54,55] and only few concentrate on specific loci $[10,53]$. The genome-wide assessment has the obvious advantage of providing concomitant evidence on multiple chromosomal loci. However, the results of the genome-wide studies [16,19-21] suggested that the concept of rare variants with high penetrance rather than the "common diseasecommon variant" hypothesis is more plausible to the etiology of schizophrenia [56]. Whereas association of common alleles could be identified by genome wide approaches, rare alleles are identified by methods which are not high throughput (such as re-sequencing of genes). When focusing on a certain candidate locus in a hypothesis-driven approach it is easier to identify rare alleles and the results obtained do not need statistical correction for multiple testing, possibly avoiding type-II error [56].

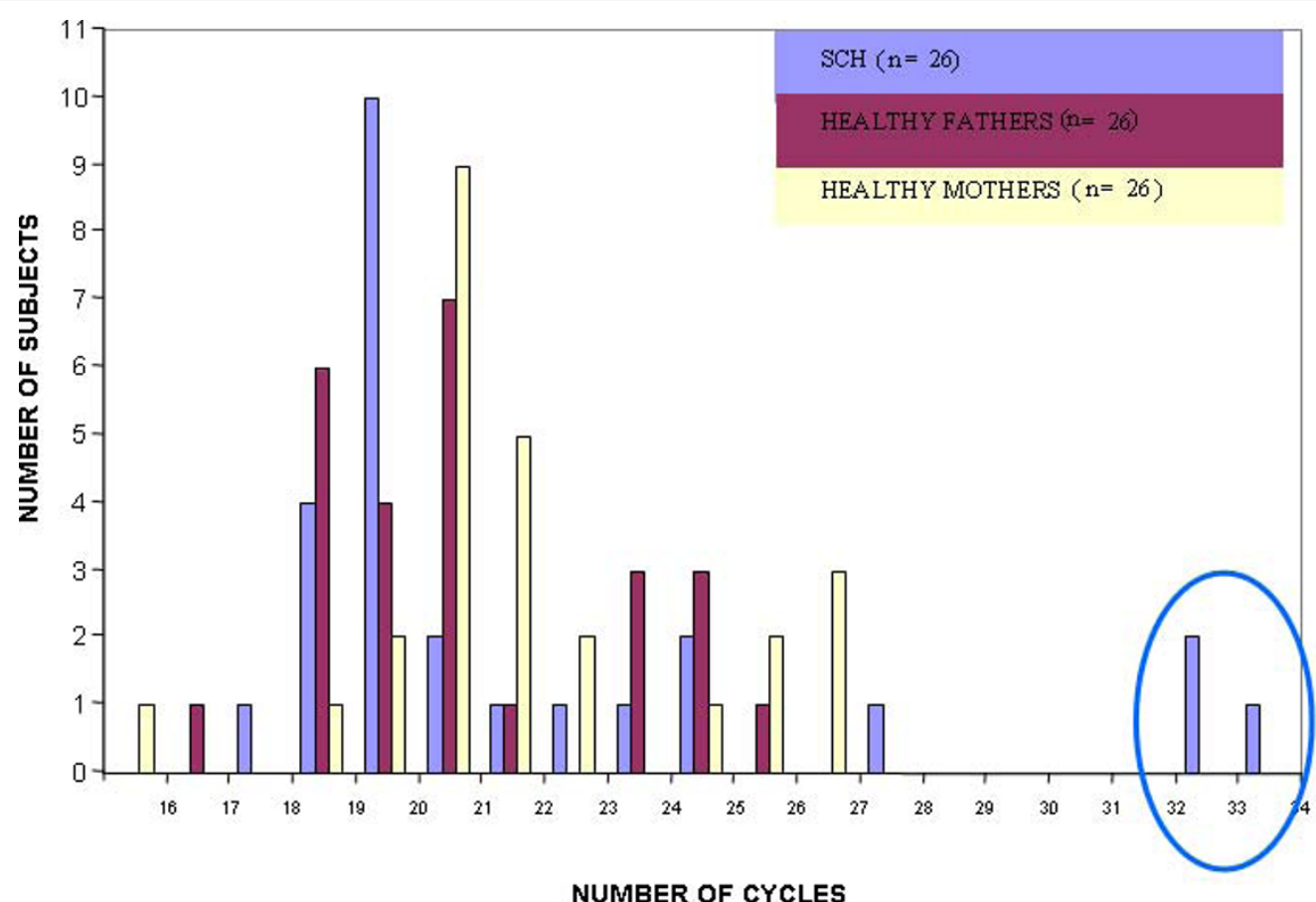

Figure $3 \mathrm{~A}$ histogram of normalized cycle number required to reach a particular fluorescence threshold of the SELENBP1 gene in blood DNA of schizophrenia probands and their healthy partents. The distribution of the normalized $C_{t}$ values of SELENBP1 in the patient group differed significantly from that of the mothers (Kolmogorov-Smirnov two-sample test, $p=0.012$ ). Circle denotes reduced copy number. 


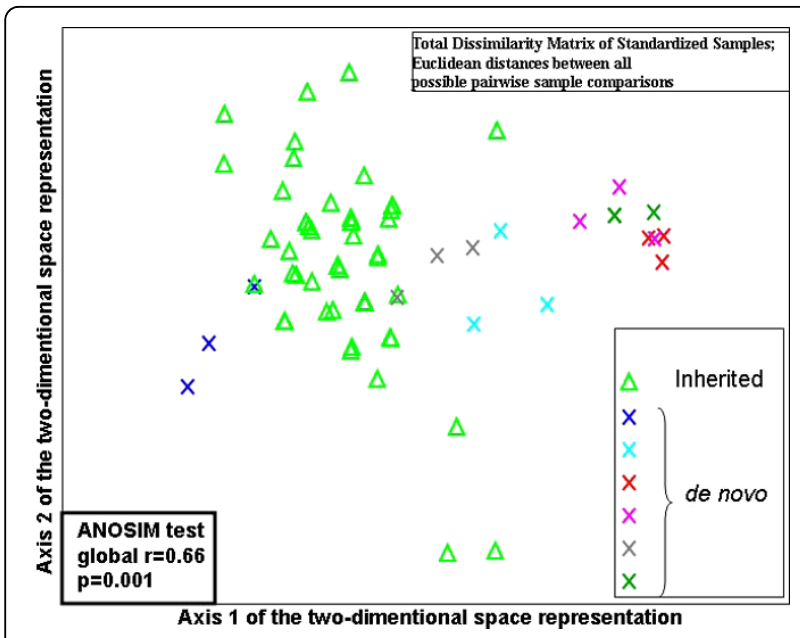

Figure 4 Two-dimensional representation of non-metric multidimensional scaling (MDS) ordination of the triads cohort. The cohort consisted of 78 samples (26 trios of schizophrenia probands and their health parents $X 3$ replicates $=78$ samples). The analysis is based on the dissimilarity matrix generated by calculating the Euclidian distance between each of the possible pairwise sample comparisons. Stress value: 0.01; A two-dimensional space representation is considered excellent when the stress value is smaller than 0.05 [50]. ANOSIM test, Global $r=0.658, p=0.001$.

Here we present three replicating experiments demonstrating notable reduction in copy number of the SELENBP1 locus in nine of the patients of the three cohorts $(n=89)$ but not in the healthy controls ( $n=$ 115) in line with previous observations of a comparable extent of CNVs in this disorder $[16,19]$. Hence, rare reduction in SELENBP1 CNVs associates with schizophrenia providing proof of concept for our working hypothesis.

Most of the probands in our triads cohort exhibited CNV patterns similar to their healthy parents, implying inherited CNV. The latter is in line with other studies suggesting that most of the CNVs are stable [1,57]. However, six out of the 26 families exhibited de novo CNV of the SELENBP1 locus, in three of whom the probands had drastically reduced copy number. Patients with de-novo CNV differed significantly from the mothers but not from the fathers. It is noteworthy that new mutations are more common in sporadic cases of disease than in cases where patients have family history of the disease [58]. Since the reduced copy number was totally attributed to de novo mutations in the triads it is tempting to speculate that the same phenomenon underlies the reduced copy number of the SELENBP1 locus among the patients in the two other sample sets. This assumption is supported by $\mathrm{Xu}$ et al [21] who showed that confirmed de novo CNV mutations are significantly associated with schizophrenia.
CNV of a gene is among possible mechanisms for a difference in its function $[1,59,60]$. The right-skewed distribution reflecting reduced copy number of the SELENBP1 locus in the postmortem cohort correlated with $16 \%$ reduction of SELENBP1 mRNA levels of this cohort. This result is in contrast with the previously reported elevated mRNA levels of this gene in postmortem frontal cortex of schizophrenia patients. The discrepancy may reflect differences in CNVs among tissues $[34,35]$ as well as documented tissue-specificity of SELENBP1 mRNA expression [61-63]. Although SELENBP1 mRNA levels of the two patients with the drastically reduced copy number of the gene's locus were below the mean of the patients' group, no linear positive correlation between the copy number and mRNA levels was obtained. It is possible that other modes of association between SELENBP1 CNV and its expression exist (e.g. a U-shaped relationship) since balanced CNVs with no functional effect in a carrier might create genomic instability only in future generations [64].

\section{Conclusions and limitations}

We show that the SELENBP1 locus which is present in variable copy number in the general human population exhibits reduced copy number in schizophrenia patients from three different cohorts. Our cohorts are of a small size but the replication in three different cohorts of two different tissues compensate for this limitation. Although no correlation was found between the copy number change and the expression level of SELENBP1 it is important to note that only part of SELENBP1 exon 12 was studied and therefore the borders of the SLENEBP1associated CNV are yet to be determined. Since this $\mathrm{CNV}$ could encompass a much larger genomic region it is possible that other factors would be affected by the copy number reduction. The reduced copy number in only $10 \%$ of the patients implies that other factors are associated with the disease in most schizophrenia cases. The general phenomenon of chromosomal instability in brain disorders [16,21,65-67], especially deletions in schizophrenia $[10,19,20]$, raises the possibility that genome integrity tends to be less protected in this disorder. If this is true multiple regions could be prone to copy number change in schizophrenia, which is in line with the multifactorial nature of the disease. Indeed, elevated induction of common fragile sites, which are hot spots for chromosomal changes $[68,69]$ have been reported in schizophrenia patients $[70,71]$. Taken together, our study underlines replicated association of reduced copy number of a given locus with schizophrenia. Further studies towards identifying candidate factors in this locus to contribute to the schizophrenia phenotype are warranted. 


\section{Acknowledgements}

The authors wish to thank their colleagues who were indispensable in the collection of the DNA samples of the three cohorts: the postmortem brain samples - B. Dean from the Rebecca L. Cooper Research Laboratories at the Mental Health Research Institute of Victoria, Australia; the blood samples - M. Rietschel and T. Schulze from the Central Institute of Mental Health, University of Heidelberg, Mannheim, Germany, supported by a grant from the Deutsche Forschungsgemeinschaft

SA is a Levi Eshkol fellow sponsored by the Israeli Ministry of Science

\section{Author details}

${ }^{1}$ Psychiatry Research Unit, Faculty of Health Sciences, Ben-Gurion University of the Negev, and Mental Health Center, Beersheva, Israel. ${ }^{2}$ Department of Life Sciences and National Institute of Biotechnology (NIBN), Ben-Gurion University of the Negev, Beer Sheva, Israel. ${ }^{3}$ Department of Psychiatry, University of Bonn, Bonn, Germany. ${ }^{4}$ Department of Psychology, Hebrew University, Mt. Scopus and S. Herzog Memorial Hospital, Jerusalem, Israel.

\section{Authors' contributions}

SA designed and carried out the experiments and prepared the first draft of the manuscript as part of her PhD thesis. OO instructed SA in the statistical analysis. WM, RE and RHB collected the cohorts of the blood samples sponsored by their grant from the Deutsche Forschungsgemeinschaft. RHB was also involved in the initiative to study CNV in schizophrenia. DM and GA instructed SA during her PhD studies. GA and SA selected SELENBP1 as the target gene for the study. All authors read and approved the final manuscript.

\section{Competing interests}

The authors declare that they have no competing interests.

Received: 27 April 2010 Accepted: 8 July 2010 Published: 8 July 2010

\section{References}

1. Cantor RM, Geschwind DH: Schizophrenia: genome interrupted. Neuron 2008, 58(2):165-167.

2. Buckland PR: Polymorphically duplicated genes: their relevance to phenotypic variation in humans. Ann Med 2003, 35(5):308-315

3. McCarroll SA, Hadnott TN, Perry GH, Sabeti PC, Zody MC, Barrett JC Dallaire S, Gabriel SB, Lee C, Daly MJ, Altshuler DM, International HapMap Consortium: Common deletion polymorphisms in the human genome. Nat Genet 2006, 38(1):86-92.

4. Nguyen DQ, Webber C, Ponting CP: Bias of selection on human copynumber variants. PLoS Genet 2006, 2(2):e20, Epub 2006 Feb 2017.

5. Redon R, Ishikawa S, Fitch KR, Feuk L, Perry GH, Andrews TD, Fiegler $H$, Shapero MH, Carson AR, Chen W, Cho EK, Dallaire S, Freeman JL, González JR, Gratacòs M, Huang J, Kalaitzopoulos D, Komura D, MacDonald JR, Marshall CR, Mei R, Montgomery L, Nishimura K, Okamura K, Shen F, Somerville MJ, Tchinda J, Valsesia A, Woodwark C, Yang F, et al: Global variation in copy number in the human genome. Nature 2006, 444(7118):444-454.

6. Repping $S$, van Daalen SK, Brown LG, Korver CM, Lange J, Marszalek JD, Pyntikova T, van der Veen F, Skaletsky H, Page DC, Rozen S: High mutation rates have driven extensive structural polymorphism among human $Y$ chromosomes. Nat Genet 2006, 38(4):463-467, Epub 2006 Feb 2026.

7. Aitman TJ, Dong R, Vyse TJ, Norsworthy PJ, Johnson MD, Smith J, Mangion J, Roberton-Lowe C, Marshall AJ, Petretto E, Hodges MD, Bhangal G, Patel SG, Sheehan-Rooney K, Duda M, Cook PR, Evans DJ, Domin J, Flint J, Boyle JJ, Pusey CD, Cook HT: Copy number polymorphism in $\mathrm{Fcgr3}$ predisposes to glomerulonephritis in rats and humans. Nature 2006, 439(7078):851-855.

8. de Vries BB, Pfundt R, Leisink M, Koolen DA, Vissers LE, Janssen IM, Reijmersdal S, Nillesen WM, Huys EH, Leeuw N, Smeets D, Sistermans EA, Feuth $T$, van Ravenswaaij-Arts CM, van Kessel AG, Schoenmakers EF, Brunner HG, Veltman JA: Diagnostic genome profiling in mental retardation. Am J Hum Genet 2005, 77(4):606-616, Epub 2005 Aug 2030

9. Feuk $L$, Marshall $C R$, Wintle RF, Scherer SW: Structural variants: changing the landscape of chromosomes and design of disease studies. Hum Mol Genet 2006, 15(Spec No 1):R57-66.

10. Friedman Jl, Vrijenhoek T, Markx S, Janssen IM, van der Vliet WA, Faas BH, Knoers NV, Cahn W, Kahn RS, Edelmann L, Davis KL, Silverman JM,
Brunner HG, van Kessel AG, Wijmenga C, Ophoff RA, Veltman JA: CNTNAP2 gene dosage variation is associated with schizophrenia and epilepsy. Mol Psychiatry 2008, 13(3):261-266, Epub 2007 Jul 2024.

11. Rovelet-Lecrux A, Hannequin D, Raux G, Le Meur N, Laquerriere A, Vital A, Dumanchin C, Feuillette S, Brice A, Vercelletto M, Dubas F, Frebourg T, Campion D: APP locus duplication causes autosomal dominant earlyonset Alzheimer disease with cerebral amyloid angiopathy. Nat Genet 2006, 38(1):24-26, Epub 2005 Dec 2020.

12. Vissers $L E$, van Ravenswaaij $C M$, Admiraal $R$, Hurst JA, de Vries $B B$, Janssen IM, van der Vliet WA, Huys EH, de Jong PJ, Hamel BC, Schoenmakers EF, Brunner HG, Veltman JA, van Kessel AG: Mutations in a new member of the chromodomain gene family cause CHARGE syndrome. Nat Genet 2004, 36(9):955-957, Epub 2004 Aug 2008.

13. Vissers $L E$, Veltman JA, van Kessel AG, Brunner HG: Identification of disease genes by whole genome CGH arrays. Hum Mol Genet 2005, 14(Spec No 2):R215-223.

14. Chubb JE, Bradshaw NJ, Soares DC, Porteous DJ, Millar JK: The DISC locus in psychiatric illness. Mol Psychiatry 2008, 13(1):36-64, Epub 2007 Oct 2002.

15. Maclntyre DJ, Blackwood DH, Porteous DJ, Pickard BS, Muir WJ: Chromosomal abnormalities and mental illness. Mol Psychiatry 2003, 8(3):275-287.

16. Walsh T, McClellan JM, McCarthy SE, Addington AM, Pierce SB, Cooper GM, Nord AS, Kusenda M, Malhotra D, Bhandari A, Stray SM, Rippey CF, Roccanova P, Makarov V, Lakshmi B, Findling RL, Sikich L, Stromberg T, Merriman B, Gogtay N, Butler P, Eckstrand K, Noory L, Gochman P, Long R, Chen Z, Davis S, Baker C, Eichler EE, Meltzer PS, et al: Rare structural variants disrupt multiple genes in neurodevelopmental pathways in schizophrenia. Science 2008, 320(5875):539-543, Epub 2008 Mar 2027.

17. Wilson GM, Flibotte S, Chopra V, Melnyk BL, Honer WG, Holt RA: DNA copynumber analysis in bipolar disorder and schizophrenia reveals aberrations in genes involved in glutamate signaling. Hum Mol Genet 2006, 15(5):743-749, Epub 2006 Jan 2024

18. Cook EH Jr, Schererq SW: Copy-number variations associated with neuropsychiatric conditions. Nature 2008, 455(7215):919-923.

19. International Schizoprenia Consortium: Rare chromosomal deletions and duplications increase risk of schizophrenia. Nature 2008, 455(7210):237-241, Epub 2008 Jul 2030.

20. Stefansson H, Rujescu D, Cichon S, Pietiläinen OP, Ingason A, Steinberg S, Fossdal R, Sigurdsson E, Sigmundsson T, Buizer-Voskamp JE, Hansen T, Jakobsen KD, Muglia P, Francks C, Matthews PM, Gylfason A, Halldorsson BV, Gudbjartsson D, Thorgeirsson TE, Sigurdsson A, Jonasdottir A, Jonasdottir A, Bjornsson A, Mattiasdottir S, Blondal T, Haraldsson M, Magnusdottir BB, Giegling I, Möller HJ, Hartmann A, et al: Large recurrent microdeletions associated with schizophrenia. Nature 2008, 455(7210):232-236

21. Xu B, Roos JL, Levy S, van Rensburg EJ, Gogos JA, Karayiorgou M: Strong association of de novo copy number mutations with sporadic schizophrenia. Nat Genet 2008, 40(7):880-885, Epub 2008 May 2030

22. Pinto D, Marshall C, Feuk L, Scherer SW: Copy-number variation in control population cohorts. Hum Mol Genet 2007, 16(Spec No 2):R168-173.

23. Wang WY, Barratt BJ, Clayton DG, Todd JA: Genome-wide association studies: theoretical and practical concerns. Nat Rev Genet 2005, 6(2):109-118.

24. Kanazawa T, Glatt SJ, Faraone SV, Hwu HG, Yoneda H, Tsuang MT: Familybased association study of SELENBP1 in schizophrenia. Schizophr Res 2009, 113(2-3):268-272.

25. Glatt SJ, Everall IP, Kremen WS, Corbeil J, Sasik R, Khanlou N, Han M, Liew CC, Tsuang MT: Comparative gene expression analysis of blood and brain provides concurrent validation of SELENBP1 up-regulation in schizophrenia. Proc Natl Acad Sci USA 2005, 102(43):15533-15538, Epub 12005 Oct 15513.

26. Kanazawa T, Chana G, Glatt SJ, Mizuno H, Masliah E, Yoneda H, Tsuang MT, Everall IP: The utility of SELENBP1 gene expression as a biomarker for major psychotic disorders: Replication in schizophrenia and extension to bipolar disorder with psychosis. Am J Med Genet B Neuropsychiatr Genet 2007, 28:28.

27. Dalla Puppa L, Savaskan NE, Brauer AU, Behne D, Kyriakopoulos A: The role of selenite on microglial migration. Ann N Y Acad Sci 2007, 1096:179-183.

28. Imai H, Nakagawa Y: Biological significance of phospholipid hydroperoxide glutathione peroxidase (PHGPx, GPx4) in mammalian cells. Free Radic Biol Med 2003, 34(2):145-169. 
29. Ogawa A, Ogawa I, Obayashi R, Umezu K, Doi M, Hirao T: Highly Selective Thioselenation of Vinylcyclopropanes with a (PhS)(2)-(PhSe)(2) Binary System and Its Application to Thiotelluration. J Org Chem 1999, 64(1):86-92.

30. Porciuncula LO, Rocha JB, Boeck CR, Vendite D, Souza DO: Ebselen prevents excitotoxicity provoked by glutamate in rat cerebellar granule neurons. Neurosci Lett 2001, 299(3):217-220.

31. Saito $Y$, Hashimoto $T$, Sasaki M, Hanaoka S, Sugai $K$, Saito $Y$, Honda M, Chikuma M: Effect of selenium deficiency on cardiac function of individuals with severe disabilities under long-term tube feeding Heparin-selenocystamine conjugate with selenol groups. Dev Med Child Neurol 1998, 40(11):743-748.

32. Yeo JE, Kang SK: Selenium effectively inhibits ROS-mediated apoptotic neural precursor cell death in vitro and in vivo in traumatic brain injury. Biochim Biophys Acta 2007, 1772(11-12):1199-1210, Epub 2007 Sep 1129.

33. Brown JS Jr: Role of selenium and other trace elements in the geography of schizophrenia. Schizophr Bull 1994, 20(2):387-398.

34. Bruder CE, Piotrowski A, Gijsbers AA, Andersson R, Erickson S, de Stahl TD, Menzel U, Sandgren J, von Tell D, Poplawski A, Crowley M, Crasto C, Partridge EC, Tiwari H, Allison DB, Komorowski J, van Ommen GJ, Boomsma DI, Pedersen NL, den Dunnen JT, Wirdefeldt K, Dumanski JP: Phenotypically concordant and discordant monozygotic twins display different DNA copy-number-variation profiles. Am J Hum Genet 2008, 82(3):763-771, Epub 2008 Feb 2014

35. Flores M, Morales L, Gonzaga-Jauregui C, Dominguez-Vidana R, Zepeda C, Yanez O, Gutierrez M, Lemus T, Valle D, Avila MC, Blanco D, Medina-Ruiz S, Meza K, Ayala E, García D, Bustos P, González V, Girard L, Tusie-Luna T, Dávila G, Palacios R: Recurrent DNA inversion rearrangements in the human genome. Proc Natl Acad Sci USA 2007, 104(15):6099-6106, Epub 2007 Mar 6026.

36. Kyriakopoulos M, Frangou S: Recent diffusion tensor imaging findings in early stages of schizophrenia. Curr Opin Psychiatry 2009, 22(2):168-176.

37. Schultz SK, Andreasen NC: Schizophrenia. Lancet 1999, 353(9162):1425-1430.

38. Buskila D, Cohen H, Neumann L, Ebstein RP: An association between fibromyalgia and the dopamine D4 receptor exon III repeat polymorphism and relationship to novelty seeking personality traits. $\mathrm{Mol}$ Psychiatry 2004, 9(8):730-731.

39. Cohen H, Buskila D, Neumann L, Ebstein RP: Confirmation of an association between fibromyalgia and serotonin transporter promoter region (5- HTTLPR) polymorphism and relationship to anxiety-related personality traits. Arthritis Rheum 2002, 46(3):845-847.

40. Levine J, Belmaker RH: Genetic epidemiology of schizoprenia in Arab communities in Israel. Psychiatric and Behavioral Disorders in Israel Jerusalem: Gefen Publishing HouseLevav I 2009, 254-266.

41. Dobrusin M, Corbex M, Kremer I, Murad I, Muhaheed M, Bannoura I, Muller DJ, Schulze TG, Reshef A, Blanaru M, Gathas S, Rietschel M, Belmaker RH, Maier W, Ebstein RP: No evidence for linkage by transmission disequilibrium test analysis of microsatellite marker D22S278 and schizophrenia in a Palestinian Arab and in a German population. Am J Med Genet 2001, 105(4):328-331.

42. Kremer I, Pinto M, Murad I, Muhaheed M, Bannoura I, Muller DJ, Schulze TG, Reshef A, Blanaru M, Gathas S, Goichman R, Rietschel M, Dobrusin M, Bachner-Melman R, Nemanov L, Belmaker RH, Maier W, Ebstein RP: Familybased and case-control study of catechol-O-methyltransferase in schizophrenia among Palestinian Arabs. Am J Med Genet B Neuropsychiatr Genet 2003, 119B(1):35-39.

43. Shamir A, Shaltiel G, Greenberg ML, Belmaker RH, Agam G: Lithium's effect on gene expression of inositol synthesis enzymes in mouse hippocampus; comparison with the yeast model. Mol Brain Res 2003, 115:104-110.

44. Wilke K, Duman B, Horst J: Diagnosis of haploidy and triploidy based on measurement of gene copy number by real-time PCR. Hum Mutat 2000, 16(5):431-436

45. Lachman HM, Pedrosa E, Petruolo OA, Cockerham M, Papolos A, Novak T, Papolos DF, Stopkova P: Increase in GSK3beta gene copy number variation in bipolar disorder. Am J Med Genet B Neuropsychiatr Genet 2007, 144B(3):259-265.

46. Shamir A, Shaltiel G, Levi I, Belmaker RH, Agam G: Postmortem parietal cortex TPH2 expression is not altered in schizophrenic unipolar- depressed, and bipolar patients vs control subjects. J Mol Neurosci 2005, 26(1):33-37

47. Sokal RR, Rohlf FJ: Biometry: the principles and practice of statistics in biological research. W.H. Freeman and Company New York, 31995

48. Clarke KR, Gorley RN: PRIMER v6: User Manual/Tutorial. Plymouth UK.: PRIMER-E Ltd 2006.

49. Kruskal JB, Wish M: Multidimensional scaling. Beverley Hills CA.: Sage Publications 1978.

50. Clarke KR, Warwick RM: Changes in marine communities: an approach to statistical analysis and interpretation. Plymouth UK: PRIMER-E Ltd, 22001.

51. Nadri C, Dean B, Scarr E, Agam G: GSK-3 parameters in postmortem frontal cortex and hippocampus of schizophrenic patients. Schizophr Res 2004, 71(2-3):377-382.

52. Vrijenhoek T, Buizer-Voskamp JE, van der Stelt I, Strengman E, Sabatti C, Geurts van Kessel A, Brunner HG, Ophoff RA, Veltman JA: Recurrent CNVs disrupt three candidate genes in schizophrenia patients. Am J Hum Genet 2008, 83(4):504-510.

53. Flomen RH, Collier DA, Osborne S, Munro J, Breen G, St Clair D, Makoff AJ: Association study of CHRFAM7A copy number and 2 bp deletion polymorphisms with schizophrenia and bipolar affective disorder. Am J Med Genet B Neuropsychiatr Genet 2006, 141B(6):571-575.

54. Stone J: Rare chromosomal deletions and duplications increase risk of schizophrenia. Nature 2008, 455(7210):237-241, Epub 2008 Jul 2030.

55. Green EK, Raybould R, Macgregor S, Gordon-Smith K, Heron J, Hyde S, Grozeva D, Hamshere M, Williams N, Owen MJ, O'Donovan MC, Jones L, Jones I, Kirov G, Craddock N: Operation of the schizophrenia susceptibility gene neuregulin 1, across traditional diagnostic boundaries to increase risk for bipolar disorder. Arch Gen Psychiatry 2005, 62(6):642-648.

56. Need AC, Ge D, Weale ME, Maia J, Feng S, Heinzen EL, Shianna KV, Yoon W, Kasperaviciute D, Gennarelli M, Strittmatter WJ, Bonvicini C, Rossi G, Jayathilake K, Cola PA, McEvoy JP, Keefe RS, Fisher EM, St Jean PL, Giegling I, Hartmann AM, Möller HJ, Ruppert A, Fraser G, Crombie C, Middleton LT, St Clair D, Roses AD, Muglia P, Francks C, et al: A genomewide investigation of SNPs and CNVs in schizophrenia. PLOS Genet 2009, 5(2):e1000373, Epub 1002009 Feb 1000376.

57. McCarroll SA: Extending genome-wide association studies to copynumber variation. Hum Mol Genet 2008, 17(R2):R135-142.

58. McCarroll SA, Kuruvilla FG, Korn JM, Cawley S, Nemesh J, Wysoker A, Shapero MH, de Bakker PI, Maller JB, Kirby A, Elliott AL, Parkin M, Hubbell E, Webster T, Mei R, Veitch J, Collins PJ, Handsaker R, Lincoln S, Nizzari M, Blume J, Jones KW, Rava R, Daly MJ, Gabriel SB, Altshuler D: Integrated detection and population-genetic analysis of SNPs and copy number variation. Nat Genet 2008, 40(10):1166-1174, Epub 2008 Sep 1167.

59. Aldred PM, Hollox EJ, Armour JA: Copy number polymorphism and expression level variation of the human alpha-defensin genes DEFA1 and DEFA3. Hum Mol Genet 2005, 14(14):2045-2052, Epub 2005 Jun 2048.

60. Bosch N, Escaramis G, Mercader JM, Armengol L, Estivill X: Analysis of the multi-copy gene family FAM90A as a copy number variant in different ethnic backgrounds. Gene 2008, 420(2):113-117, Epub 2008 May 2013.

61. GeneCards Version 2. Weizmann Institute of Science:Applied Biosystems TaqMan Gene Expression Assays for SELENBP1 2010.

62. Lanfear J, Fleming J, Walker M, Harrison P: Different patterns of regulation of the genes encoding the closely related $56 \mathrm{kDa}$ selenium- and acetaminophen-binding proteins in normal tissues and during carcinogenesis. Carcinogenesis 1993, 14(3):335-340.

63. Zhao A, Tang H, Lu S, He R: Identification of a differentially-expressed gene in fatty liver of overfeeding geese. Acta Biochim Biophys Sin (Shanghai) 2007, 39(9):649-656.

64. Feuk $L$, Carson $A R$, Scherer SW: Structural variation in the human genome. Nat Rev Genet 2006, 7(2):85-97.

65. Helbig I, Mefford HC, Sharp AJ, Guipponi M, Fichera M, Franke A, Muhle H, de Kovel C, Baker C, von Spiczak S, Kron KL, Steinich I, Kleefuss-Lie AA Leu C, Gaus V, Schmitz B, Klein KM, Reif PS, Rosenow F, Weber Y, Lerche H, Zimprich F, Urak L, Fuchs K, Feucht M, Genton P, Thomas P, Visscher F, de Haan GJ, Møller RS, et al: 15q13.3 microdeletions increase risk of idiopathic generalized epilepsy. Nat Genet 2009, 41(2):160-162, Epub 2009 Jan 2011.

66. Porteous DJ, Thomson P, Brandon NJ, Millar JK: The genetics and biology of DISC1-an emerging role in psychosis and cognition. Biol Psychiatry 2006, 60(2):123-131. 
67. Sebat J, Lakshmi B, Malhotra D, Troge J, Lese-Martin C, Walsh T, Yamrom B, Yoon S, Krasnitz A, Kendall J, Leotta A, Pai D, Zhang R, Lee YH, Hicks J, Spence SJ, Lee AT, Puura K, Lehtimäki T, Ledbetter D, Gregersen PK, Bregman J, Sutcliffe JS, Jobanputra V, Chung W, Warburton D, King MC, Skuse D, Geschwind DH, Gilliam TC, et al: Strong association of de novo copy number mutations with autism. Science 2007, 316(5823):445-449, Epub 2007 Mar 2015.

68. Glover TW: Common fragile sites. Cancer Lett 2006, 232(1):4-12, Epub 2005 Oct 2017.

69. Glover TW, Arlt MF, Casper AM, Durkin SG: Mechanisms of common fragile site instability. Hum Mol Genet 2005, 14(Spec No 2):R197-205.

70. Chen $\mathrm{CH}$, Shih HH, Wang-Wuu S, Tai JJ, Wuu KD: Chromosomal fragile site expression in lymphocytes from patients with schizophrenia. Hum Genet 1998, 103(6):702-706.

71. Demirhan O, Tastemir D, Sertdemir Y: Chromosomal fragile sites in schizophrenic patients. Genetika 2006, 42(7):985-992.

doi:10.1186/1744-9081-6-40

Cite this article as: Amar et al:: Copy number variation of the SELENBP1 gene in schizophrenia. Behavioral and Brain Functions 2010 6:40.

\section{Submit your next manuscript to BioMed Central} and take full advantage of:

- Convenient online submission

- Thorough peer review

- No space constraints or color figure charges

- Immediate publication on acceptance

- Inclusion in PubMed, CAS, Scopus and Google Scholar

- Research which is freely available for redistribution

Submit your manuscript at www.biomedcentral.com/submit 